\title{
Effects of Predators on the Belowground Life Stages (Prepupae and Pupae) of the Western Flower Thrips, Frankliniella occidentalis (Thripidae: Thysanoptera): A Review
}

\author{
Raymond A. Cloyd \\ Department of Entomology, Kansas State University, Manhattan, KS, USA \\ Email: rcloyd@ksu.edu
}

How to cite this paper: Cloyd, R.A. (2019) Effects of Predators on the Belowground Life Stages (Prepupae and Pupae) of the Western Flower Thrips, Frankliniella occidentalis (Thripidae: Thysanoptera): A Review. Advances in Entomology, 7, 71-80. https://doi.org/10.4236/ae.2019.74006

Received: July 22, 2019

Accepted: August 12, 2019

Published: August 15, 2019

Copyright $\odot 2019$ by author(s) and Scientific Research Publishing Inc. This work is licensed under the Creative Commons Attribution International License (CC BY 4.0).

http://creativecommons.org/licenses/by/4.0/ (c) (i) Open Access

\begin{abstract}
Western flower thrips, Frankliniella occidentalis, is a major cosmopolitan insect pest causing direct and indirect damage to greenhouse-grown horticultural crops. The primary way of managing western flower thrips populations is by routinely applying insecticides, which target the aboveground life stages: larvae and adult. However, insecticides are minimally effective against the pupal stages (prepupae and pupae) that reside in the growing medium or soil. Therefore, soil-dwelling biological control agents including: predatory mites [Stratiolaelaps scimitus and Hypoaspis = (Geolaelaps) aculeifer], and a rove beetle, Dalotia coriaria may be a viable option to induce mortality on the pupal stages. These predators will feed on the pupal stages of the western flower thrips and can provide mortality on a life stage that is tolerant of insecticide applications. However, these biological control agents need to be used in conjunction with other plant protection strategies, such as insecticides and/or biological control agents that target the aboveground life stages (larvae and adult) to effectively manage western flower thrips populations in greenhouse production systems.
\end{abstract}

\section{Keywords}

Predatory Mites, Rove Beetle, Growing Medium, Biological Control, Predation

\section{Introduction}

Western flower thrips, Frankliniella occidentalis (Pergande) (Thysanoptera: Thripidae), is one of the most destructive insect pests worldwide associated with 
greenhouse-grown horticultural crops, including vegetables and ornamentals [1] [2] [3] [4]. Western flower thrips causes direct and indirect plant damage [5] [6]. Direct damage caused by larvae and adults when feeding on leaves, flowers, and fruits can result in leaf, flower, and fruit scarring; sunken tissues on leaf undersides; distortion and discoloration of flowers; and fruit deformation [2] [7] [8] [9]. Indirect damage is affiliated with adults vectoring plant viruses, including the tospoviruses: Tomato spotted wilt and Impatiens necrotic spot virus [10] [11] [12]. Consequently, greenhouse producers regularly apply insecticides to suppress western flower thrips populations below damaging levels [4] [13] [14]. However, the cost of continually using insecticides can be expensive [15] [16] and oftentimes leads to resistance developing in western flower thrips populations [17] [18] [19] [20].

The western flower thrips life cycle consists of an egg, two larval stages (instars), two pupal stages (prepupae and pupae), and an adult [21] [22]. Eggs are inserted into plant tissues and first instar larvae eclose from eggs [20] [23]. Second instar larvae eventually stop feeding and migrate down the plant stem or drop onto the surface of the growing medium or soil to pupate [16] [24] [25] [26]. Holmes et al. (2012) [27] reported that larvae primarily drop from plants instead of walking down plant stems. As noted, there are two pupal stages: prepupae and pupae. Western flower thrips prepupae take two to three days to develop into pupae, and pupae take one to two days to develop into adults [28] [29].

The pupal stages do not feed and are not as mobile as larvae and adults [29] [30]. In addition, the pupal stages are less susceptible to insecticides commonly applied to suppress populations of the larvae and adults [31]. Western flower thrips pupates in the growing medium of plant containers or in the soil underneath benches in greenhouses. Pupae can reside at a depth of 1.0 to $5.0 \mathrm{~mm}$ although this is contingent on the growing medium or soil type [25]. Tommasini and Maini (1995) [21] indicated that pupation occurred at a depth of 1.5 to 2.0 $\mathrm{cm}$ and Deligeorgidis and Ipsilandis (2004) [32] reported that almost half of a western flower thrips population pupated in the top $2.0 \mathrm{~cm}$ of soil.

Eighty-six to $90 \%$ of western flower thrips pupated on the soil with green bean, Phaseolus vulgaris, plants [33] [34]. Buitenhuis and Shipp (2008) [35] found that 92 and $93 \%$ of western flower thrips pupated in the soil of non-flowering chrysanthemum, Dendranthema $\times$ grandiflorum, and rose, Rosa spp., plants, respectively. A study reported that 92 and $99 \%$ of larvae associated with flowering chrysanthemum and cucumber, Cucumis sativus, plants, respectively, pupated in the soil [27]. Berndt et al. (2004) [36] indicated that 98\% of a western flower thrips population left bean plants and pupated in the soil. The growing medium and soil likely provide a suitable environment for survival, based on moisture content, relative humidity, physical structure, and temperature [32] [36] [37] [38].

While western flower thrips seems to prefer pupating in the growing medium or soil [39], they will also pupate on aboveground portions such as leaves or 
flowers of certain plant types [16] [30] [40] [41]. For example, studies have reported that western flower thrips will pupate in the complex inflorescences (flowers) of chrysanthemum plants [35] [42]. Factors that can influence western flower thrips pupating on plants include: relative humidity, host plant species, and plant growth stage [38] [42].

The proportion of western flower thrips that pupate in the growing medium or soil is likely affected by host plant species [43]. In addition, pupating in the growing medium or soil reduces exposure to aboveground biological control agents [36] including the predatory mite, Neoseiulus $=($ Amblyseius $)$ cucumeris (Oudemans) (Acari: Phytoseiidae), and the insidious flower bug, Orius insidiosus (Say) (Hemiptera: Anthocoridae) [44] [45] [46] [47] [48].

However, pupating in the growing medium or soil exposes prepupae and pupae to soil-dwelling predators [49] [50], and, because they are less mobile than larvae and adults, this increases their risk of predation [30] [51]. Due to the short duration time of the prepupae and pupae (one to three days), predators only have a "narrow window of opportunity" to prey upon the pupal stages [38] [52]. Soil-dwelling predatory mites and a rove beetle can cause mortality on the pupal stages of western flower thrips residing in the growing medium or soil [36] [52].

However, these biological control agents need to be used in conjunction with other plant protection strategies, such as insecticides and/or biological control agents that target the aboveground life stages (larvae and adult) so as to effectively manage western flower thrips populations in greenhouse production systems.

\section{Predatory Mites}

The soil-dwelling predatory mites, Stratiolaelaps scimitus (Womersley) (Acari: Laelapidae), which was formerly called "Hypoaspis miles" (Berlese), and Hypoaspis $=($ Geolaelaps) aculeifer Canestrini (Acarina: Laelapidae), have been used to regulate populations of the pupal stages of western flower thrips residing in the soil [36] [53]. Females are 0.7 to $1.0 \mathrm{~mm}$ in length and possess a pale-brown dorsal shield [54] [55] [56]. Hypoaspis aculeifer may feed on western flower thrips pupal stages more so than $S$. scimitus [26]. Berndt et al. (2004) [36] reported that releasing $H$. miles or $H$. aculeifer, respectively, resulted in a 44.9 to $57.6 \%$ population reduction in western flower thrips densities. The results suggest that $H$. aculeifer may have a higher predation efficacy than $H$. miles. However, western flower thrips pupae may not be a preferred food source (prey) for these two predatory mites [36]. Consequently, this would reduce their efficacy in regulating populations of the pupal stages in the growing medium or soil in the presence of alternate prey.

Studies have evaluated the potential of releasing two predatory mites simultaneously [57]. For instance, Wiethoff et al. (2004) [26] found that combining the predatory mite, $N$. cucumers, for the aboveground life stages with the predatory mite, $H$. aculeifer, for the belowground life stages, did not increase control of 
western flower thrips compared to just using $N$. cucumeris alone. In addition, predatory mites have been applied in conjunction with entomopathogenic nematodes [50] [58]. A study found that combining the predatory mite, H. aculeifer, with the entomopathogenic nematodes, Steinernema feltiae Filipjev and $\mathrm{He}$ terorhabditis bacteriophora Poinar, reduced western flower thrips adult eclosion by 71 to $82 \%$ [59]. However, Manners et al. (2013) [16] found that applying aboveground and belowground predators was no more effective in reducing western flower thrips numbers than only applying aboveground predators. In addition, releasing two biological control agents simultaneously may be cost prohibitive [16] or lead to intraguild predation, where multiple predators interfere with each other for a shared prey source [60] [61].

\section{Predatory Beetle}

The soil-dwelling predatory rove beetle, Dalotia (formerly Atheta) coriaria (Kraatz) (Coleoptera: Staphylinidae), is commercially available from most biological control suppliers [62] [63]. Adults are dark-brown to shiny-black and 3 to $4 \mathrm{~mm}$ in length [64]. The early instar larvae are creamy white, whereas later instar larvae are yellow-brown [56]. Both adults and larvae are predacious, feeding on the larval stages of a number of greenhouse insect pests including: shore fly (Scatella spp.) and fungus gnat (Bradysia spp.) larvae [56] [65] [66]. Moreover, rove beetles will feed on western flower thrips prepupae and pupae. For example, Carney et al. (2002) [67] reported that one D. coriaria adult consumed 78 western flower thrips pupae in 24 hours, whereas another study found that one $D$. coriaria adult preyed upon approximately 28 prepupae in 24 hours (Yinping Li, unpublished data). Both studies were conducted in petri dishes under laboratory conditions. A recent study conducted in 11.5 and $15.2 \mathrm{~cm}$ plastic containers under laboratory conditions found that rove beetles feed on the pupal stages (prepupae and pupae) of western flower thrips and can substantially lower adult emergence from the growing medium [52]. The study determined that the number of rove beetles released influences predation efficacy. For example, at least three rove beetle adults are needed to provide sufficient regulation of western flower thrips pupal populations based on predation under the initial numbers of western flower thrips prepupae and pupae $(15,20,25$, and 30) tested. In addition, a 1:15 predator-prey ratio (rove beetle adult-western flower thrips pupal stages) resulted in the highest predation efficacy ( $<40 \%$ of western flower thrips adults captured on yellow sticky cards) associated with $D$. coriaria [52].

\section{Conclusions}

Studies show that certain predatory mites and the rove beetle, D. coriaria, may be viable biological control options targeting the pupal stages of western flower thrips in the growing medium or soil [52]. Consequently, the release of predatory mites and rove beetles in greenhouse production systems may induce mortality on a life stage that has been difficult to suppress using insecticides. In addi- 
tion, releasing predatory mites and/or rove beetles may reduce inputs from insecticide applications; thus mitigating issues associated with insecticide resistance.

However, the predatory mites and rove beetle cannot be relied upon as the only source of mortality for western flower thrips in greenhouse production systems. Nonetheless, both may be used in conjunction with aboveground biological control agents that feed on the larvae and adult life stages of western flower thrips [36] [49] [59], or foliar applications of insecticides, especially since a mixed population structure (eggs, larvae, pupae, and adults) of western flower thrips will likely be present under greenhouse conditions.

\section{Acknowledgements}

I want to thank Dr. Nathan J. Herrick in the Department of Entomology and Dr. Mary Beth Kirkham in the Department of Agronomy at Kansas State University (Manhattan, KS) for reviewing an initial draft of the manuscript.

\section{Conflicts of Interest}

The author declares no conflicts of interest regarding the publication of this paper.

\section{References}

[1] Robb, K.L. and Parrella, M.P. (1995) IPM of Western Flower Thrips. In: Parker, B.L., Skinner, M. and Lewis, T., Eds., Thrips Biology and Management, Plenum Press, New York, 365-370. https://doi.org/10.1007/978-1-4899-1409-5_56

[2] Lewis, T. (1997) Major Crops Infested by Thrips with Main Symptoms and Predominant Injurious Species. In: Lewis, T., Ed., Thrips as Crop Pests, CAB International, Wallingford, 675-709.

[3] Kirk, W.D.J. (2002) The Pest from the West: Frankliniella occidentalis. Thrips and Tospoviruses: Proceedings of the 7 th International Symposium on Thysanoptera, Vol. 2, 33-42.

[4] Cloyd, R.A. (2009) Western Flower Thrips (Frankliniella occidentalis) Management on Ornamental Crops Grown in Greenhouses: Have We Reached an Impasse? Pest Technology, 3, 1-9.

[5] Allen, W.R. and Broadbent, A. (1986) Transmission of Tomato Spotted Wilt Virus in Ontario Greenhouses by Frankliniella occidentalis. Canadian Journal of Plant Pathology, 8, 33-38. https://doi.org/10.1080/07060668609501838

[6] Pappu, H., Jones, R.A.C. and Jain, R.K. (2009) Global Status of Tospovirus Epidemics in Diverse Cropping Systems: Successes Achieved and Challenges Ahead. Virus Research, 141, 219-236. https://doi.org/10.1016/j.virusres.2009.01.009

[7] Chisholm, I.F. and Lewis, T. (1984) A New Look at Thrips (Thysanoptera) Mouthparts, Their Action and Effects of Feeding on Plant Tissue. Bulletin of Entomological Research, 74, 663-675. https://doi.org/10.1017/S0007485300014048

[8] van Dijken, F.R., Dik, M.T.A., Gebala, B., de Jong, J. and Mollema, C. (1994) Western Flower Thrips (Thysanoptera: Thripidae) Effects of Chrysanthemum Cultivars: Plant Growth and Leaf Scarringin Nonflowering Plants. Journal of Economic Entomology, 87, 1313-1317. https://doi.org/10.1093/jee/87.5.1312 
[9] Childers, C.C. (1997) Feeding and Oviposition Injuries to Plants. In: Lewis, T., Ed., Thrips as Crop Pests, CAB International, New York, 505-537.

[10] van de Wetering, F., Goldbach, R. and Peters, D. (1996) Tomato Spotted Wilt Tospovirus Ingestion by First Instar Larvae of Frankliniella occidentalis Is a Prerequisite for Transmission. Phytopathology, 86, 900-905.

https://doi.org/10.1094/Phyto-86-900

[11] Daughtrey, M.L., Jones, R.K., Moyer, J.W., Daub, M.E. and Baker, J.R. (1997) Tospoviruses Strike the Greenhouse Industry. Plant Disease, 81, 1220-1230. https://doi.org/10.1094/PDIS.1997.81.11.1220

[12] Whitfield, A.E., Ullman, D.E. and German, T.L. (2005) Tospovirus-Thrips Interactions. Annual Review of Phytopathology, 43, 459-489.

https://doi.org/10.1146/annurev.phyto.43.040204.140017

[13] Kontsedalov, S., Weintraub, P.G., Horowitz, A.R. and Ishaaya, I. (1998) Effects of Insecticides on Immature and Adult Western Flower Thrips (Thysanoptera: Thripidae) in Israel. Journal of Economic Entomology, 91, 1067-1071. https://doi.org/10.1093/jee/91.5.1067

[14] Loughner, R.L, Warnock, D.F. and Cloyd, R.A. (2005) Resistance of Greenhouse, Laboratory and Native Populations of Western Flower Thrips to Spinosad. HortScience, 40, 146-149. https://doi.org/10.21273/HORTSCI.40.1.146

[15] Murphy, B.C., Morisawa, T.A., Newman, J.P., Tjosvold, S.A. and Parrella, M.P. (1998) Fungal Pathogen Controls Thrips in Greenhouse Flowers. California Agriculture, 52, 32-36. https://doi.org/10.3733/ca.v052n03p32

[16] Manners, A.G., Dembowski, B.R. and Healey, M.A. (2013) Biological Control of Western Flower Thrips, Frankliniella occidentalis (Pergande), in Gerberas, Chrysanthemums and Roses. Australian Journal of Entomology, 52, 246-258. https://doi.org/10.1111/aen.12020

[17] Jensen, S.E. (2000) Insecticide Resistance in the Western Flower Thrips, Frankliniella occidentalis. Integrated Pest Management Review, 5, 131-146. https://doi.org/10.1023/A:1009600426262

[18] Herron, G.A. and James, T.M. (2005) Monitoring Insecticide Resistance in Australian Frankliniella occidentalis Pergande (Thysanoptera: Thripidae) Detects Fipronil and Spinosad Resistance. Australian Journal of Entomology, 44, 299-303. https://doi.org/10.1111/j.1440-6055.2005.00478.x

[19] Bielza, P. (2008) Insecticide Resistance Management Strategies against the Western Flower Thrips, Frankliniella occidentalis. Pest Management Science, 64, 1131-1138. https://doi.org/10.1002/ps.1620

[20] Cloyd, R.A. (2015) Western Flower Thrips (Thysanoptera: Thripidae) and Insecticide Resistance: An Overview and Strategies to Mitigate Insecticide Resistance Development. Journal of Entomological Science, 51, 257-273. https://doi.org/10.18474/JES16-15.1

[21] Tommasini, M.G. and Maini, S. (1995) Frankliniella occidentalis and Thrips Harmful to Vegetable and Ornamental Crops in Europe. In: Loomans, A.J.M., van Lenteren, J.C., Tommasini, S., Maini, S. and Riudavets, J., Eds., Biological Control of Thrips Pests, Wageningen Agricultural University Papers 95, Wageningen, 1-42.

[22] Reitz, S.R. (2009) Biology and Ecology of the Western Flower Thrips (Thysanoptera: Thripidae): The Making of a Pest. Florida Entomologist, 92, 7-13. https://doi.org/10.1653/024.092.0102

[23] Terry, L.I. (1997) Host Selection, Communication and Reproductive Behaviour. In: 
Lewis, T., Ed., Thrips as Crop Pests, CAB International, Wallingford, 65-118.

[24] Gaum, W.G., Giliomee, J.H. and Pringle, K.L. (1994) Life History and Life Tables of Western Flower Thrips, Frankliniella occidentalis (Thysanoptera: Thripidae), on English Cucumbers. Bulletin of Entomological Research, 84, 219-224. https://doi.org/10.1017/S0007485300039729

[25] Helyer, N.L., Brobyn, P.J., Richardson, P.N. and Edmondson, R.N. (1995) Control of Western Flower Thrips (Frankliniella occidentalis Pergande) Pupae in Compost. Annals of Applied Biology, 127, 405-412. https://doi.org/10.1111/j.1744-7348.1995.tb07600.x

[26] Wiethoff, J., Poehling, H.M. and Meyhöfer, R. (2004) Combining Plant and Soil-Dwelling Predatory Mites to Optimize Biological Control of Thrips. Experimental and Applied Acarology, 34, 239-261.

https://doi.org/10.1023/B:APPA.0000049137.26697.b9

[27] Holmes, N.D., Bennison, J.A., Maulden, K.A. and Kirk, W.D.J. (2012) The Pupation Behaviour of the Western Flower Thrips, Frankliniella occidentalis (Pergande). Acta Phytopathologica et Entomologica Hungarica, 47, 87-96. https://doi.org/10.1556/APhyt.47.2012.1.11

[28] Robb, K.L., Parrella, M.P. and Newman, J.P. (1988) The Biology and Control of Western Flower Thrips. Part I. Ohio Florists Association Bulletin, 699, 2-5.

[29] Zhang, Z.J., Wu, Q.J., Li, X.F., Zhang, Y.J., Xu, B.Y. and Zhu, G.R. (2007) Life History of Western Flower Thrips, Frankliniella occidentalis (Thysan., Thripidae), on Five Different Vegetable Leaves. Journal of Applied Entomology, 131, 347-354. https://doi.org/10.1111/j.1439-0418.2007.01186.x

[30] Lewis, T. (1973) Thrips: Their Biology, Ecology and Economic Importance. Academic Press, New York.

[31] Seaton, K.A., Cook, D.F. and Hardie, D.C. (1997) The Effectiveness of a Range of Insecticides against Western Flower Thrips (Frankliniella occidentalis) (Thysanoptera: Thripidae) on Cut Flowers. Australian Journal of Agricultural Research, 48, 781-787. https://doi.org/10.1071/A96081

[32] Deligeorgidis, P.N. and Ipsilandis, C.G. (2004) Determination of Soil Depth Inhabited by Frankliniella occidentalis (Pergande) and Thrips tabaci Lindeman (Thysan., Thripidae) under Greenhouse Cultivation. Journal of Applied Entomology, 128, 108-111. https://doi.org/10.1111/j.1439-0418.2003.00815.x

[33] Ebssa, L., Borgemeister, C., Berndt, O. and Poehling, H.-M. (2001) Impact of Entomopathogenic Nematodes on Different Soil-Dwelling Stages of Western Flower Thrips, Frankliniella occidentalis (Thysanoptera: Thripidae), in the Laboratory and under Semi-Field Conditions. Biocontrol Science and Technology, 11, 515-525. https://doi.org/10.1080/09583150120067544

[34] Ebssa, L. (2005) Efficacy of Entomopathogenic Nematodes for the Control of the Western Flower Thrips Frankliniella occidentalis. PhD Thesis, University of Hanover, Hannover. https://doi.org/10.1016/j.biocontrol.2006.02.005

[35] Buitenhuis, R. and Shipp, J.L. (2008) Influence of Plant Species and Plant Growth Stage on Frankliniella occidentalis Pupation Behaviour in Greenhouse Ornamentals. Journal of Applied Entomology, 132, 86-88.

https://doi.org/10.1111/j.1439-0418.2007.01250.x

[36] Berndt, O., Meyhöfer, R. and Poehling, H-M. (2004) The Edaphic Phase in the Ontogenesis of Frankliniella occidentalis and Comparison of Hypoaspis miles and Hypoaspis aculeifer as Predators of Soil-Dwelling Thrips Stages. Biological Control, 30, 17-24. https://doi.org/10.1016/j.biocontrol.2003.09.009 
[37] Kakei, Y. and Tsuchida, K. (2000) Influences of Relative Humidity on Mortality during the Pupal Stage of Thrips palmi (Thysanoptera; Thripidae). Applied Entomology and Zoology, 35, 63-67. https://doi.org/10.1303/aez.2000.63

[38] Steiner, M.Y., Spohr, L.J. and Goodwin, S. (2011) Relative Humidity Controls Pupation Success and Dropping Behaviour of Western Flower Thrips, Frankliniella occidentalis (Pergande) (Thysanoptera: Thripidae). Australian Journal of Entomology, 50, 179-186. https://doi.org/10.1111/j.1440-6055.2010.00798.x

[39] Varatharajan, R. and Daniel, A.M. (1984) Studies on Soil Pupation in Some Phytophagous Thrips. Journal of Soil Biology and Ecology, 4, 116-123.

[40] Jacobson, R.J. (1997) Integrated Pest Management in Glasshouses. In: Lewis, T., Ed., Thrips as Crop Pests, CAB International, Wallingford, 639-666.

[41] Bennison. J., Broadbent, B., Kirk, W., Maulden, W.K. and Shipp, L. (2004) Western Flower Thrips Pupation Behavior on Greenhouse Chrysanthemum and Implications for Integrated Control. Proceedings of the International Congress of Entomology, Brisbane, 15-21 August 2004, Abstract.

[42] Broadbent, A.B., Rhainds, M., Shipp, L., Murphy, G. and Wainman, L. (2003) Pupation Behavior of Western Flower Thrips (Thysanoptera: Thripidae) on Potted Chrysanthemum. Canadian Entomologist, 135, 741-744.

https://doi.org/10.4039/n03-007

[43] Berndt, O. (2002) Entomopathogenic Nematodes and Soil-Dwelling Predatory Mites: Suitable Antagonists for Enhanced Biological of Frankliniella occidentalis (Pergande) (Thysanoptera: Thripidae)? PhD Thesis, University of Hanover, Hannover, 129 p.

[44] Gillespie, D.R. (1989) Biological Control of Thrips [Thysanoptera: Thripidae] on Greenhouse Cucumber by Amblyseius cucumeris. Entomophaga, 34, 185-192. https://doi.org/10.1007/BF02372667

[45] van Houten, Y.M., van Rijn, P.C.J., Tanigoshi, L.K., van Stratum, P. and Bruin, J. (1995) Preselection of Predatory Mites to Improve Year-Around Biological Control of Western Flower Thrips in Greenhouse Crops. Entomologia Experimentalis et Applicata, 74, 225-234. https://doi.org/10.1111/j.1570-7458.1995.tb01895.x

[46] De Courcy Williams, M.E. (2001) Biological Control of Thrips on Ornamental Crops: Interactions between the Predatory Mite Neoseiulus cucumeris (Acari: Phytoseiidae) and Western Flower Thrips, Frankliniella occidentalis (Thysanoptera: Thripidae), on Cyclamen. Biocontrol Science and Technology, 11, 41-55. https://doi.org/10.1080/09583150020029736

[47] Shipp, J.L. and Wang, K. (2003) Evaluation of Amblyseius cucumeris (Acari: Phytoseiidae) and Orius insidiosus (Hemiptera: Anthocoridae) for Control of Frankliniella occidentalis (Thysanoptera: Thripidae) on Greenhouse Tomatoes. Biological Control, 28, 271-281. https://doi.org/10.1016/S1049-9644(03)00091-4

[48] Baez, I., Reitz, S.R. and Funderburk, J.E. (2004) Predation by Orius insidiosus (Heteroptera: Anthocoridae) on Life Stages and Species of Frankliniella Flower Thrips (Thysanoptera: Thripidae) in Pepper Flowers. Environmental Entomology, 33, 662-670. https://doi.org/10.1603/0046-225X-33.3.662

[49] Gillespie, D.R. and Quiring, D.M.J. (1990) Biological Control of Fungus Gnats, Bradysia spp. (Diptera: Sciaridae), and Western Flower Thrips, Frankliniella occidentalis (Pergande) (Thysanoptera: Thripidae), in Greenhouses Using a Soil-Dwelling Predatory Mite, Geolaelaps sp. nr. aculeifer (Canestrini) (Acari: Laelapidae). Canadian Entomologist, 122, 975-983. https://doi.org/10.4039/Ent122975-9

[50] Pozzebon, A., Boaria, A. and Duso, C. (2015) Single and Combined Releases of Biological Control Agents against Canopy- and Soil-Dwelling Stages of Frankliniella 
occidentalis in Cyclamen. BioControl, 60, 341-350. https://doi.org/10.1007/s10526-014-9641-4

[51] Kirk, W.D.J. (1996) Thrips. In: Corget, S.A. and Disney, R.H.L., Eds., Naturalists' Handbook, Vol. 25, Richmond Publishing, Slough, 70 p.

[52] Li, Y. (2019) Effects of Rove Beetle, Dalotia coriaria, on Western Flower Thrips, Frankliniella occidentalis, under Laboratory Conditions; and Integrating the Entomopathogenic Fungus, Beauveria bassiana, with $D$. coriaria to Suppress Western Flower Thrips Populations under Greenhouse Conditions. PhD Dissertation, Department of Entomology, Kansas State University, Manhattan, 176 p.

[53] Van Lenteren, J.C. and Loomans, A.J.M. (1998) Is There a Natural Enemy Good Enough for Biological Control of Thrips? Proceedings of the International Brighton Crop Protection Conference-Pests \& Diseases, Brighton, 16-19 November 1998, Vol. 35, 401-408.

[54] Walter, D.E. and Campbell, N.J.H. (2003) Exotic vs. Endemic Biocontrol Agents: Would the Real Stratiolaelaps miles (Berlese) (Acari: Mesostigmata: Laelapidae), Please Stand up? Biological Control, 26, 253-269.

https://doi.org/10.1016/S1049-9644(02)00171-8

[55] Malais, M.H. and Ravensberg, W.J. (2003) Knowing and Recognizing: The Biology of Glasshouse Pests and Their Natural Enemies. Reed Business Information, Amsterdam.

[56] Helyer, N., Cattlin, N.D. and Brown, K.C. (2014) Biological Control in Plant Protection: A Color Handbook. Second Edition, CRC Press, Taylor \& Francis Group, Boca Raton. https://doi.org/10.1201/b16042

[57] Wu, S., Zhang, Z., Gao, Y., Xu, X. and Lei, Z. (2016) Interactions between Foliageand Soil-Dwelling Predatory Mites and Consequences for Biological Control of Frankliniella occidentalis. BioControl, 61, 717-727. https://doi.org/10.1007/s10526-016-9762-z

[58] Saito, T. and Brownbridge, M. (2016) Compatibility of Soil-Dwelling Predators and Microbial Agents and Their Efficacy in Controlling Soil-Dwelling Stages of Western Flower Thrips Frankliniella occidentalis. Biological Control, 92, 92-100. https://doi.org/10.1016/j.biocontrol.2015.10.003

[59] Premachandra, W.T.S.D., Borgemeister, C., Berndt, O., Ehlers, R.-U. and Poehling, H.-M. (2003) Combined Releases of Entomopathogenic Nematodes and the Predatory Mite Hypoaspis aculeifer to Control Soil-Dwelling Life Stages of Western Flower Thrips Frankliniella occidentalis. BioControl, 48, 529-541. https://doi.org/10.1023/A:1025703512113

[60] Polis, G.A., Myers, C.A. and Holt, R.D. (1989) The Ecology and Evolution of Intraguild Predation: Potential Competitors That Eat Each Other. Annual Review of Ecology and Systematics, 20, 297-330. https://doi.org/10.1146/annurev.es.20.110189.001501

[61] Rosenheim, J.A., Kaya, H.K., Ehler, L.E., Marois, J.J. and Jaffee, B.A. (1995) Intraguild Predation among Biological Control Agents: Theory and Evidence. Biological Control, 5, 303-335. https://doi.org/10.1006/bcon.1995.1038

[62] Jandricic, S., Murphy, G., Broadbent, A.B., Scott-Dupree, C.D. and Harris, C.R. (2005) Compatibility of Atheta coriaria with Other Biocontrol Agents Used in Greenhouse Production. International Organization for Biological and Integrated Control/ West Palaearctic Regional Section Bulletin, 28, 135-138. https://doi.org/10.4039/n05-106

[63] Warner, K.D. and Getz, C. (2008) A Socio-Economic Analysis of the North American Commercial Natural Enemy Industry and Implications for Augmentative Bio- 
logical Control. Biological Control, 45, 1-10.

https://doi.org/10.1016/j.biocontrol.2007.12.003

[64] Miller, K.V. and Williams, R.N. (1983) Biology and Host Preference of Atheta coriaria (Coleoptera: Staphylinidae), an Egg Predator of Nitidulidae and Muscidae. Annals of the Entomological Society of America, 76, 158-161.

https://doi.org/10.1093/aesa/76.2.158

[65] Jandricic, S., Scott-Dupree, C.D., Broadbent, A.B., Harris, C.R. and Murphy, G. (2006) Compatibility of Atheta coriaria with Other Biological Control Agents and Reduced-Risk Insecticides Used in Greenhouse Floriculture Integrated Pest Management Programs for Fungus Gnats. Canadian Entomologist, 138, 712-722. https://doi.org/10.4039/n05-106

[66] Echegaray, E.A., Cloyd, R.A. and Nechols, J.R. (2015) Rove Beetle (Coleoptera: Staphylinidae) Predation on Bradysia sp. nr. coprophila (Diptera: Sciaridae). Journal of Entomological Science, 50, 225-237. https://doi.org/10.18474/JES14-38.1

[67] Carney, V.A., Diamond, J.C., Murphy, G.D. and Marshall, D. (2002) The Potential of Atheta coriaria Kraatz (Coleoptera: Staphylinidae), as a Biological Control Agent for Use in Greenhouse Crops. International Organization for Biological and Integrated Controll West Palaearctic Regional Section Bulletin, 25, 37-40. 